\title{
ANALISIS TINGKAT KEMANFAATAN KNOWLEDGE SHARING TERHADAP KARYAWAN DENGAN MENGGUNAKAN METODE TECHNOLOGY ACCEPTANCE MODEL (TAM)
}

\author{
Nesdi Evrilyan Rozanda ${ }^{1}$, Rizki Nur Jannah Hasibuan ${ }^{2}$ \\ ${ }^{1,2}$ Program Studi Sistem Informasi, Universitas Islam Sultan Syarif Kasim Riau, 28293, Indonesia \\ nesdi.rozanda@uin-suska.ac.id rizkinurjannah09@gmail.com
}

\begin{abstract}
Abstrak
PT. PLN Sektor Pembangkitan Pekanbaru mempunyai sistem knowledge management PLN (KM PLN), berfungsi sebagai media knowledge sharing (KS) seperti pengetahuan terbaru, best practice,inovasi, lessond learned,cara penurun an gangguan penyulang murai (SUTM), upaya penurunan gangguan system rayon, penurunan gangguan penyulang poli o, karbon dan kwarto. Pengetahuan ini berguna untuk meningkatkan kualitas kerja karyawan dalam menyelesaikan peke rjaannya. Penelitian ini menggunakan metode Technology Acceptance Model untuk analisis tingkat kemanfaatan KS ter hadap karyawan, dengan menggunakan 5 konstruk yaitu Perceived Usefulness, Perceived Ease Of Use, Attitude Towar ds Using Technology, Behavioral Intention To Use dan Actual Technology Use. Kuesioner dibagikan kepada seluruh ka ryawan yang berjumlah 57 orang, guna untuk mengetahui konstruk yang paling bermanfaat, Penelitian ini menggunaka $\mathrm{n}$ analisis regresi linear berganda. Hasil dari penelitian menunjukkan konstruk perceived ease of use dalam kategori setuju dengan nilai tertinggi, Sedangkan nilai terendah terdapat pada konstruk perceived usefulness.
\end{abstract}

Kata kunci: Knowledge Sharing, Sistem Knowledge Management PL, Technology Acceptance Model.

\section{PENDAHULUAN}

Knowledge management (KM) merupakan seran gkaian proses mengubah data dan informasi menjadi pengetahuan [1]. Untuk menciptakan KM dengan efektif, sangat diperlukan budaya menciptaka dan menumbuhkan KS. Tanpa adanya proses KS maka proses learning bagi seluruh karyawan akan terlambat, tanpa learning tidak akan ada inovasi, tanpa inovasi suatu organisasi tidak akan tumbuh atau bahkan tidak dapat bertahan. Adanya knowledge tools dapat membantu pimpinan dan organisas i dalam merangsang karyawan untuk melakukan sharing pengetahuan. Knowledge tools merupakan alat bantu yang dibutuhkan untuk KS [2].

Pengetahuan terbagi menjadi dua jenis yaitu pengetahuan tacit dan pengetahuan eksplisit. Pengetahua $\mathrm{n}$ tacit adalah pengetahuan yang ada di dalam otak/pikiran sesuai dengan pemahaman, keahlian dan pengalaman. Sedangkan pengetahuan eksplisit adalah pengetahuan yang telah didokumentasikan sehingga lebih mudah dipahami dan disebarluaskan. Metode transfer pengetahuan yang sering digunakan oleh penelitian adalah Model SECI yang dikemukakan oleh Nonaka dan Takeuchi. Komponen yang terdapat dalam model SECI [3].
Delpi Group dalam dalam Bambang Setiarsono melakukan riset tentang komposisi pengetahuan yang tersimpan dalam struktur antara lain $42 \%$ di pikiran atau otak karyawan, $26 \%$ dokumen kertas, $20 \%$ dokumen elektronik dan $12 \%$ knowledge base elektronik Artinya sebesar $42 \%$ pengetahuan yang masih berada di pikiran atau otak masing-masing individu inilah yang perlu mendapatkan ruang atau sarana sehingga dapat disampaikan atau dikomunikasikan kepada orang lain [4]. Sehingga tidak hanya menambah pengetahuan atau informasi orang tersebut namun juga bisa mendorong memunculkan lahirnya suatu ide atau gagasan baru untuk menciptakan produk atau sistem baru atau juga melakukan perbaikan pada produk atau sistem yang lama.

Knowledge management dianggap sebagai suatu entitas yang sistematik yang berupaya memperluas, mengolah, dan menerapkan pengetahuan yang tersedia dengan cara memberikan nilai tambah pada entitas dalam mencapai tujuan. Knowledge management system dicipta kan untuk memfasilitasi penangkapan, penyimpanan, pencarian, transfer dan penggunaan kembali pengetahuan [5].

Knowledge Management PLN adalah media komunikasi internal perusahaan yang dipergunakan untuk 
KS perusahaan yang dapat dilakukan oleh antar individu ke kelompok, bahkan perusahaan ke kelompok. knowledge Management PLN memiliki kecepatan yang sangat tinggi, sehingga dapat mendukung berbagai kegiatan komunikasi antar karyawan Pengetahuan disharing oleh karyawan yang kompeten di bidangnya dan diterima oleh seluruh karyawan, PT. PLN Sektor mempunyai karyawan sebanyak 57 orang dan semua karyawan menggunakan sistem KM PLN untuk saling sharing antara karyawan dan pimpinan .

KS karyawan dan inovasi-inovasi baru juga sangat dibutuhkan untuk melakukan transformasi yang telah dicanangkan demi mewujudkan visi PT. PLN "Diakui sebagai organisasi kelas dunia yang bertumbuh kembang, unggul dan terpercaya dengan bertumpu pada potensi insani" sebagai perusahaan yang menjadikan pengetahuan sebagai bagian utama dari perusahaan. Masalah pada sistem KM PLN 1. Terdapat ruang diskusi akan tetapi tidak digunakan sebagai tempat diskusi ataupun rapat dan seharusnya dimanfaatkan agar terwujudnya KS yang baik dan ketika karyawan di luar kantor bisa mendapatkan atau sharing seputar pengetahuan terbaru yang ia peroleh dilapangan. 2. Dalam fitur-fitur KS tidak terdapat kolom komentar dan karyawan hanya bisa membaca tanpa bisa memberikan komentar dengan apa yang ia terima.3. Ketika karyawan melakukan sharing tentang pengetahuan terbaru sering terjadi proses yang lamban karena kendala jaringan.

Akibat dari masalah-masalah tersebut KS menjadi lamban dan karyawan tidak bisa langsung melakukan diskusi dan rapat ketika berada di luar kantor. Akibat tidak adanya kolom komentar pada kolom KS membuat KS hanya sebatas disitu saja, dan tidak bisa saling tukar pikiran antara sesama karyawan karena ia hanya bisa membaca saja.

Penelitian terdahulu yaitu prediksi tingkat keyakinan mahasiswa akan manfaat fasilitas KRS online dengan metode technology acceptance model [6]. Dalam penelitian ini dilakukan analisis dengan melihat manfaat dari konstruk persepsi kebermanfaatan (perceived usefulnes), persepsi kemudahan pengguna (perceived ease of use), sikap terhadap prilaku (attitude towards using technology), intensitas perilaku pengguna (behavioral intention to use), pengguna teknologi sesungguhnya (actual technology use).

Berdasarkan pentingnya KS dalam PT. PLN maka dilakukan penelitian dengan judul "Analisis Tingkat
Kemanfaat Knowledge Sharing Terhadap Karyawan Dengan Menggunakan Metode Technology Acceptance Model (TAM)".

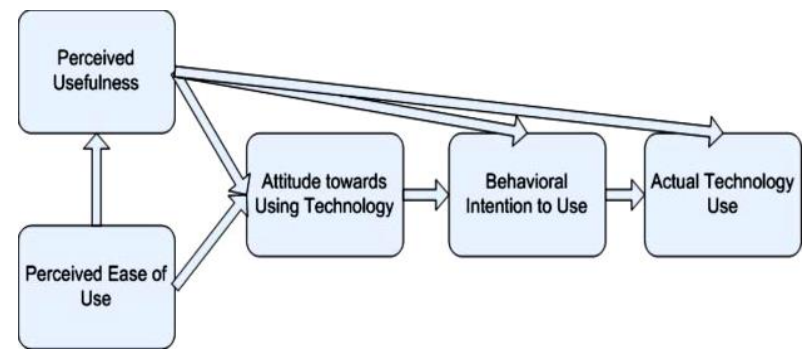

Gambar 1 Technology Acceptance Model (Davis 1989)

TAM merupakan salah satu jenis teori yang menggunakan pendekatan teori perilaku (behavioral theory) yang banyak digunakan untuk mengkaji proses adopsi teknologi informasi [7]. Bagaimanapun yang namanya model yang bagus itu tidak hanya memprediksi, namun idealnya juga harus bisa menjelaskan. Rupanya dengan model TAM dan indikatornya memang sudah teruji dapat mengukur penerimaan teknologi. Dengan demikian menggunakan TAM maka akan mampu menjelaskan KS yang digunakan di PT. PLN Sektor Pekanbaru bisa diterima atau tidak oleh pengguna sehingga dapat memberikan manfaat. TAM memberikan dasar untuk mengetahui pengaruh faktor eksternal terhadap kepercayaan, sikap, dan tujuan dari penggunanya.

Menurut Davis, TAM merupakan adaptasi dari Theory of Reasoned Action Model (TRA) yang secara khusus telah disesuaikan dengan model penerimaan sistem informasi oleh pengguna/user. TAM memiliki dua sisi yaitu sisi pertama atau yang biasa disebut beliefs yang terdiri atas perceived usefulness dan perceived ease-of use dan sisi yang kedua terdiri dari attitude, behavior intention to use dan actual use [8 ]. Model TAM sebenarnya adalah adopsi dari theory of reaasoned action (TRA) yang mempelajari model dari psikologi sosial yang berkaitan dengan faktor penentu sebuah prilaku [9].

Dari hasil wawancara yang telah dilakukan dapat diketahui bahwa sistem KM PLN dalam hal KS digunakan karyawan PT. PLN Sektor Pekanbaru, dan yang paling sering menggunakan sistem KM PLN adalah bagian sumber daya manusia (SDM) dan bagian operasi dan pemeliharaan. 


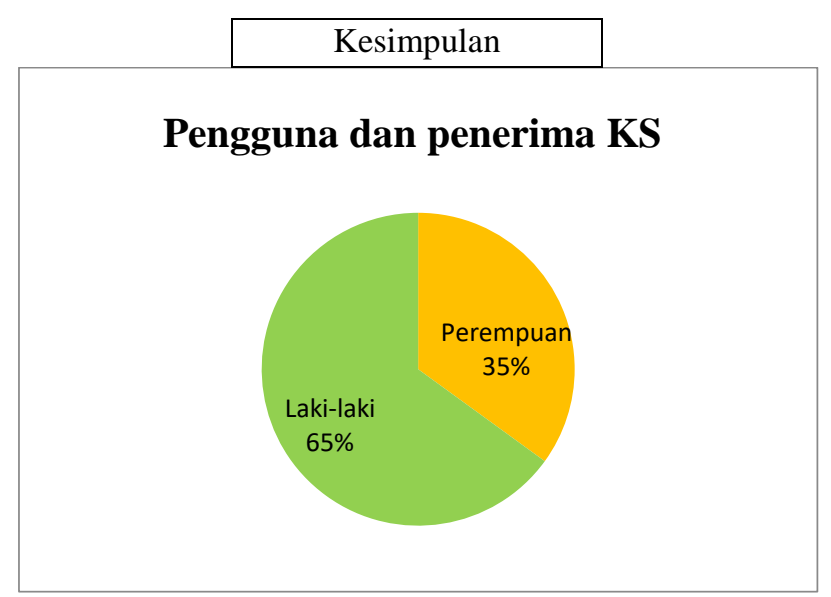

Grafik 2 Pengguna Dan Penerima Sistem KM PLN pada KS

Dari grafik di atas dapat diketahui bahwa yang paling sering melakukan KS adalah bagian sumber daya manusia, dan yang merasakan manfaatnya adalah bagian operasi dan pemeliharaan dan dapat disimpulkan yang paling sering melakukan KS adalah laki-laki yaitu sebanyak $65 \%$.

\section{METODOLOGI}

Penelitian ini terdiri dari enam tahapan, yaitu: Tahap Pendahuluan, Tahap Perencanaan, Tahap Pengumpulan Data, Tahap Pengolahan Data, Tahap Analisis Data dan Tahap Dokumentasi.

Gambar 3. Metodologi Penelitian

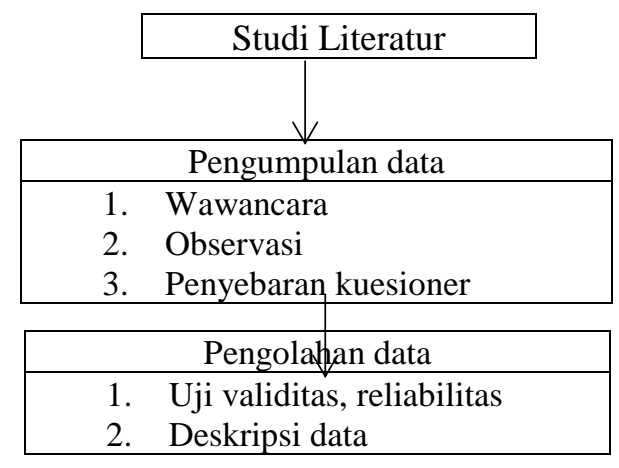

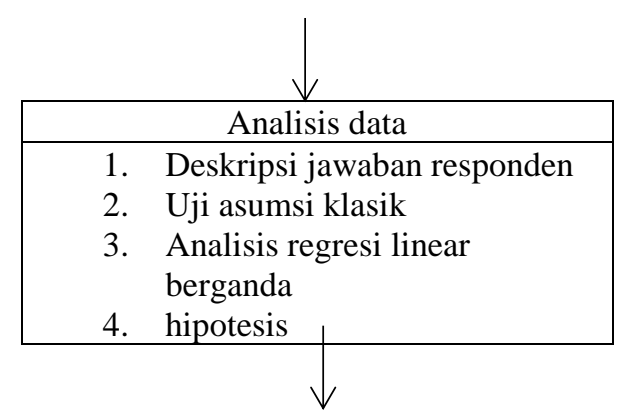

Pengumpulan data dilakukan dengan cara wawancara langsung dengan beberapa user sistem KM PLN mengenai KS Wawancara ini bertujuan untuk mengetahui kendala apa saja yang dihadapi user terhadap $\mathrm{KS}$, siapa saja yang boleh menggunakan KS, manfaat KS terhadap kinerja karyawan dan melakukan observasi.

TABEL I

Skala Likert

\begin{tabular}{|l|l|l|l|l|}
\hline \multicolumn{5}{|c|}{ Keterangan intensitas kesetujuan pertanyaan } \\
dalam kuesioner
\end{tabular}

TABEL II

Keterangan Kuesioner

\begin{tabular}{|l|l|}
\hline \multicolumn{1}{|c|}{ Keterangan } & \multicolumn{1}{c|}{ Jumlah kuesioner } \\
\hline Kuesioner yang disebar & 57 \\
\hline Kuesioner yang kembali & 57 \\
\hline $\begin{array}{l}\text { Kuesioner yang tidak } \\
\text { kembali }\end{array}$ & 0 \\
\hline Kuesioner yang bisa di olah & 57 \\
\hline
\end{tabular}

\section{PENGOLAHAN DATA}

1) Uji Validitas

Pengujian validitas dilakukan terhadap butiran pertanyaan dari pertanyaan kuesioner yang akan dibagi kepada karyawan yang berjumlah 57 orang responden, dengan jumlah pertanyaan 20 butir yang terdiri dari 4 pertanyaan untuk konstruk PU (X1), 5 pertanyaan untuk konstruk PEOU (X2), 3 pertanyan untuk konstruk ATUT (X3), 4 pertanyaan untuk konstruk BITU (X4) dan 4 pertanyaan untuk konstruk ATU (Y).

Pengujian dilakukan dengan cara membandingk an nilai korelasi product moment atau biasa disebut dengan $r$ tabel dengan $r$ hitung, dimana $r$ hitung harus lebih 
besar besar dari r tabel. Di dalam tabel r Product Moment untuk jumlah 57 responden dengan taraf signifikan $5 \%$ adalah 0.423 .

TABEL III

Uji Validitas

\begin{tabular}{|c|c|c|c|}
\hline \multicolumn{4}{|c|}{ Usefulness (X1) } \\
\hline Pertanyaan & $\begin{array}{l}\text { Nilai Korelasi } \\
\text { (person correl } \\
\text { ation) }\end{array}$ & $\mathrm{R}_{\text {tabel }}$ & Keterangan \\
\hline Pertanyaan 1 & 0.789 & 0.307 & Valid \\
\hline Pertanyaan 2 & 0.805 & 0.307 & Valid \\
\hline Pertanyaan 3 & 0.439 & 0.307 & Valid \\
\hline Pertanyaan 4 & 0.505 & 0.307 & Valid \\
\hline \multicolumn{4}{|c|}{ Ease of use (X2) } \\
\hline Pertanyaan & $\begin{array}{l}\text { Nilai Korelasi } \\
\text { (person } \\
\text { correlation) }\end{array}$ & Rtabel & Keterangan \\
\hline Pertanyaan 1 & 0.796 & 0.307 & Valid \\
\hline Pertanyaan 2 & 0.303 & 0.307 & Tidak Valid \\
\hline Pertanyaan 3 & 0.307 & 0.307 & Valid \\
\hline Pertanyaan 4 & 0.456 & 0.307 & Valid \\
\hline Pertanyaan 5 & 0.548 & 0.307 & Valid \\
\hline \multicolumn{4}{|c|}{ Attitude towards using technology (X3) } \\
\hline Pertanyaan & $\begin{array}{l}\text { Nilai Korelasi } \\
\text { (person } \\
\text { correlation) }\end{array}$ & Rtabel & Keterangan \\
\hline Pertanyaan 1 & 0.663 & 0.307 & Valid \\
\hline Pertanyaan 2 & 0.629 & 0.307 & Valid \\
\hline Pertanyaan 3 & 0.776 & 0.307 & Valid \\
\hline \multicolumn{4}{|c|}{ Behavioral intention to use (X4) } \\
\hline Pertanyaan & $\begin{array}{l}\text { Nilai Korelasi } \\
\text { (person } \\
\text { correlation) }\end{array}$ & Rtabel & Keterangan \\
\hline Pertanyaan 1 & 0.462 & 0.307 & Valid \\
\hline Pertanyaan 2 & 0.474 & 0.307 & Valid \\
\hline Pertanyaan 3 & 0.571 & 0.307 & Valid \\
\hline Pertanyaan 4 & 0.578 & 0.307 & Valid \\
\hline \multicolumn{4}{|c|}{ Actual technology use (Y) } \\
\hline Pertanyaan & $\begin{array}{l}\text { Nilai Korelasi } \\
\text { (person } \\
\text { correlation) }\end{array}$ & $\mathrm{R}_{\text {tabel }}$ & Keterangan \\
\hline Pertanyaan 1 & 0.653 & 0.307 & Valid \\
\hline Pertanyaan 2 & 0.597 & 0.307 & Valid \\
\hline Pertanyaan 3 & 0.552 & 0.307 & Valid \\
\hline Pertanyaan 4 & 0.732 & 0.307 & Valid \\
\hline
\end{tabular}

Dapat diketahui bahwa setiap item pertanyaan adalah valid dan hanya satu pertanyaan yang tidak valid. Pertanyaan yang valid sesuai dengan nilai korelasi lebih besar dari $r$ tabel.

TABEL IV

Uji Reliabilitas

\begin{tabular}{|c|c|c|c|c|}
\hline Pertanyaan & $\begin{array}{l}\text { ALPHA IF } \\
\text { ITEM } \\
\text { DELETED }\end{array}$ & $\begin{array}{l}\text { Cronba } \\
\text { ch } \\
\text { Alpha }\end{array}$ & $\begin{array}{l}\text { Nilai } \\
\text { Alpha }\end{array}$ & Keterangan \\
\hline Pertanyaan 1 & 0.653 & \multirow[t]{4}{*}{0.741} & 0.600 & Reliable \\
\hline Pertanyaan 2 & 0.662 & & 0.600 & Reliable \\
\hline Pertanyaan 3 & 0.768 & & 0.600 & Reliable \\
\hline Pertanyaan 4 & 0.749 & & 0.600 & Reliable \\
\hline \multicolumn{5}{|c|}{ Ease of use (X2) } \\
\hline Pertanyaan & $\begin{array}{l}\text { ALPHA IF } \\
\text { ITEM } \\
\text { DELETED }\end{array}$ & $\begin{array}{l}\text { Cronba } \\
\text { ch } \\
\text { Alpha }\end{array}$ & $\begin{array}{l}\text { Nilai } \\
\text { Alpha }\end{array}$ & Keterangan \\
\hline Pertanyaan 1 & 0.535 & \multirow[t]{5}{*}{0.670} & 0.600 & $\begin{array}{l}\text { Tidak } \\
\text { Reliable }\end{array}$ \\
\hline Pertanyaan 2 & 0.684 & & 0.600 & Reliable \\
\hline Pertanyaan 3 & 0.682 & & 0.600 & Reliable \\
\hline Pertanyaan 4 & 0.658 & & 0.600 & Reliable \\
\hline Pertanyaan 5 & 0.641 & & 0.600 & Reliable \\
\hline \multicolumn{5}{|c|}{ Attitude towards using technology (X3) } \\
\hline Pertanyaan & $\begin{array}{l}\text { ALPHA IF } \\
\text { ITEM } \\
\text { DELETED }\end{array}$ & $\begin{array}{l}\text { Cronba } \\
\text { ch } \\
\text { Alpha }\end{array}$ & $\begin{array}{l}\text { Nilai } \\
\text { Alpha }\end{array}$ & Keterangan \\
\hline Pertanyaan 1 & 0.763 & \multirow[t]{3}{*}{0.776} & 0.600 & Reliable \\
\hline Pertanyaan 2 & 0.781 & & 0.600 & Reliable \\
\hline Pertanyaan 3 & 0.686 & & 0.600 & reliable \\
\hline \multicolumn{5}{|c|}{ Behavioral intention to use (X4) } \\
\hline Pertanyaan & $\begin{array}{l}\text { ALPHA IF } \\
\text { ITEM } \\
\text { DELETED }\end{array}$ & $\begin{array}{l}\text { Cronba } \\
\text { ch } \\
\text { Alpha }\end{array}$ & $\begin{array}{l}\text { Nilai } \\
\text { Alpha }\end{array}$ & Keterangan \\
\hline Pertanyaan 1 & 0.663 & \multirow[t]{4}{*}{0.604} & 0.600 & Reliable \\
\hline Pertanyaan 2 & 0.630 & & 0.600 & Reliable \\
\hline Pertanyaan 3 & 0.617 & & 0.600 & Reliable \\
\hline Pertanyaan 4 & 0.593 & & 0.600 & $\begin{array}{l}\text { Tidak } \\
\text { Reliable }\end{array}$ \\
\hline \multicolumn{5}{|c|}{ Actual technology use $(\mathrm{Y})$} \\
\hline Pertanyaan & $\begin{array}{l}\text { ALPHA IF } \\
\text { ITEM } \\
\text { DELETED }\end{array}$ & $\begin{array}{l}\text { Cronba } \\
\text { ch } \\
\text { Alpha }\end{array}$ & $\begin{array}{l}\text { Nilai } \\
\text { Alpha }\end{array}$ & Keterangan \\
\hline Pertanyaan 1 & 0.704 & \multirow[t]{4}{*}{0.740} & 0.600 & Reliable \\
\hline Pertanyaan 2 & 0.727 & & 0.600 & Reliable \\
\hline Pertanyaan 3 & 0.733 & & 0.600 & Reliable \\
\hline Pertanyaan 4 & 0.675 & & 0.600 & Reliable \\
\hline
\end{tabular}

Diketahui bahwa setiap item pertanyaan adalah reliable sesuai dengan pengukuran standarisasi cronbach alpha, nilai lebih besar dari 0.600 .

\section{2) Deskripsi Data}

Dari hasil wawancara yang telah dilakukan kepada pengguna sistem KM PLN, yang menggunakan KS, maka dapat disimpulkan bahwa sistem KM PLN adalah alat untuk saling tukar pikiran atau media berbagi pengetahuan, tentang pengetahuan terbaru dan berkomunikasi antar karyawan yang dapat membantu karyawan dalam menyelesaikan pekerjaan. Sistem KM PLN ini melibatkan hampir seluruh pekerjaan sehingga karyawan sangat membutuhkan sistem KM PLN untuk bertukar informasi.

\section{ANALISIS DAN HASIL}

Dari hasil wawancara yang telah dilakukan kepada pengguna sistem KM PLN, yang melakukan KS, maka dapat disimpulkan bahwa sistem KM PLN adalah alat untuk saling tukar pikiran atau media berbagi 
Jurnal Ilmiah Rekayasa dan Manajemen Sistem Informasi, Vol. 5, No. 1, Februari 2019, Hal. 78-85

e-ISSN 2502-8995 p-ISSN 2460-8181

pengetahuan, tentang pengetahuan terbaru dan berkomunikasi antar karyawan yang dapat membantu karyawan dalam menyelesaikan pekerjaan. Sistem KM PLN ini melibatkan hampir seluruh pekerjaan sehingga karyawan sangat membutuhkan sistem KM PLN untuk bertukar informasi. Pengetahuan berupa tata cara mengerjakan suatu pekerjaan seperti cara penurunan gangguan, hal-hal yang harus dilakukan dan hal-hal yang dilarang, sosialisasi mengenai project baru perusahaan dan mengenai perubahan cara kerja atau proses bisnis pada perusahaan.

1. Deskripsi Jawaban Responden Pada Variabel usefulness (X1)

TABEL V

Pertanyaan Perceived Usefulness

\begin{tabular}{|l|l|l|l|l|l|}
\hline \multicolumn{5}{|c|}{ Pertanyaan1 } \\
\hline \multicolumn{2}{|c|}{} & & & $\begin{array}{l}\text { Valid } \\
\text { Frequency }\end{array}$ & $\begin{array}{l}\text { Cumulativ } \\
\text { e Percent }\end{array}$ \\
\hline \multirow{3}{*}{ Valid } & 1 & 6 & 10.5 & 10.5 & 10.5 \\
\cline { 2 - 6 } & 2 & 18 & 31.6 & 31.6 & 42.1 \\
\cline { 2 - 6 } & 3 & 23 & 40.4 & 40.4 & 82.5 \\
\cline { 2 - 6 } & 4 & 10 & 17.5 & 17.5 & 100.0 \\
\cline { 2 - 6 } & Total & 57 & 100.0 & 100.0 & \\
\hline
\end{tabular}

Dari hasil pengolahan data kuesioner yang telah dilakukan pada item pertanyaan 1 variabel usefulness dinyatakan bahwa hasil jawaban responden tertinggi adalah $40.4 \%$ setuju.

2. Deskripsi Jawaban Responden Pada Variabel ease of use (X2)

TABEL VI

Pertanyaan Perceived Ease Of Use

\begin{tabular}{|l|l|r|r|r|r|}
\hline \multicolumn{7}{|c|}{ Pertanyaan 1 } \\
\hline \multirow{3}{*}{ Valid } & 1 & Frequency & Percent & $\begin{array}{c}\text { Valid } \\
\text { Percent }\end{array}$ & $\begin{array}{c}\text { Cumulative } \\
\text { Percent }\end{array}$ \\
\cline { 2 - 6 } & 2 & 5 & 8.8 & 8.8 & 8.8 \\
\cline { 2 - 6 } & 3 & 12 & 21.1 & 21.1 & 29.8 \\
\cline { 2 - 6 } & 4 & 33 & 57.9 & 57.9 & 87.7 \\
\cline { 2 - 6 } & Total & 6 & 10.5 & 10.5 & 98.2 \\
\hline
\end{tabular}

Dari hasil pengolahan data kuesioner yang telah dilakukan pada item pertanyaan 1 variabel Ease Of Use dinyatakan bahwa hasil jawaban responden tertinggi adalah $57.9 \%$ setuju.

\section{Uji Asumsi Klasik}

Berikut ini adalah pengujian yang dilakukan sebelum dilakukannya analisis regresi berganda, yaitu:

1) Uji Normalitas

Deteksi normalitas dilakukan dengan melihat grafik Normal Probability Plot. Untuk menguji apakah distribusi data normal atau tidak, dapat dilakukan dengan melihat grafik normal probability plot yang membandingkan distribusi kumulatif dari data sesungguhnya dengan distribusi kumulatif dari distribusi normal. Jika data menyebar di sekitar garis dan mengikuti arah garis diagonal maka model regresi memenuhi asumsi normalitas tetapi jika data menyebar jauh dari garis diagonal dan atau mengikuti arah garis diagonal maka model regresi tidak memenuhi asumsi normalitas. Hasil dan histogram uji normalitas dapat dilihat pada gambar berikut :

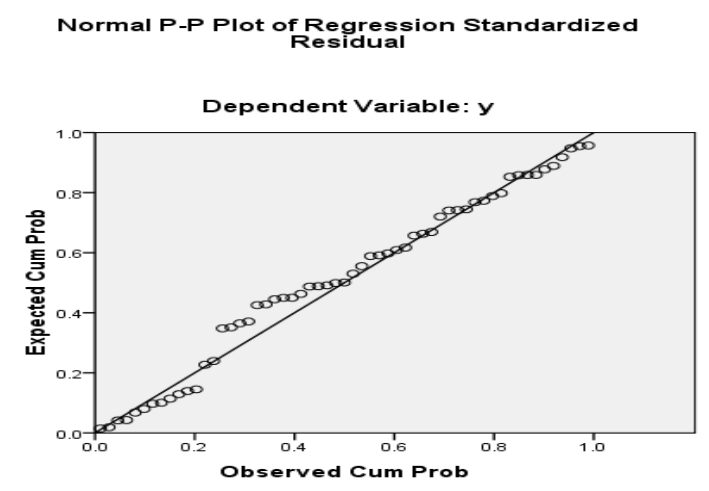

Gambar 4. Uji Normalitas

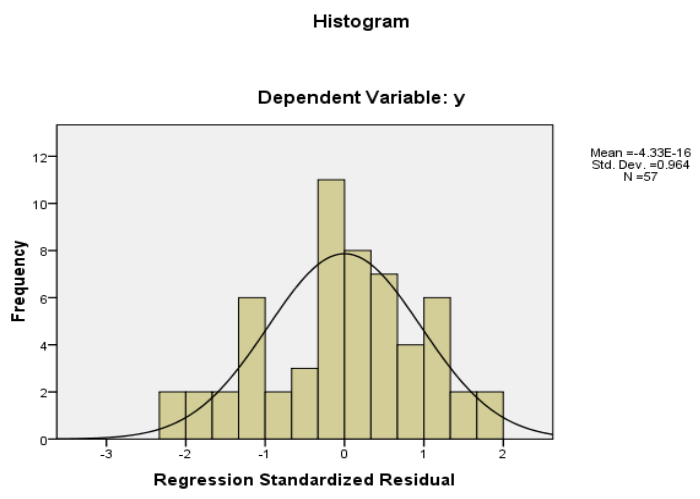

Gambar 5. Uji Histogram Normalitas 
Dengan melihat tampilan histogram maupun grafik normal plot pada semua variabel penerimaan sistem dapat disimpulkan bahwa pada grafik normal plot terlihat titik-titik menyebar disekitar garis diagonal serta penyebarannya mengikuti arah garis diagonal. Sedangkan grafik histogram, memberikan pola distribusi yang normal. Kedua grafik ini menunjukkan bahwa model regresi memenuhi uji normalitas.

2) Uji Autokorelasi

Untuk menguji apakah ada masalah autokorelasi dalam persamaan regresi sederhana, maka dilakukan uji Durbin-Watson.

Ketentuan:

1. Angka D-W dibawah -2 berarti ada autokorelasi

2. Angka DW diantara -2 sampai 2 berarti tidak ada autokorelasi

3. Angka DW diatas 2 berarti ada autokorelasi

TABEL VII

Uji Autokorelasi

\begin{tabular}{|c|c|c|c|c|c|}
\hline \multicolumn{6}{|c|}{ Model Summary ${ }^{b}$} \\
\hline Model & $\mathrm{R}$ & R Square & $\begin{array}{l}\text { Adjusted R } \\
\text { Square }\end{array}$ & $\begin{array}{l}\text { Std. Error } \\
\text { of the } \\
\text { Estimate }\end{array}$ & $\begin{array}{l}\text { Durbin- } \\
\text { Watson }\end{array}$ \\
\hline 1 & $\begin{array}{r}.49 \\
2^{\mathrm{a}}\end{array}$ & .242 & .183 & 1.390 & 1.453 \\
\hline \multicolumn{6}{|c|}{ a. Predictors: (Constant), x4, x3, x1, x2 } \\
\hline
\end{tabular}

Diketahui bahwa nilai Durbin-Watson (D-W) sebesar 1.453 yang terletak antara -2 sampai 2 maka tidak terjadi autokorelasi pada model yang dibuat.

\section{3) Uji Multikolineritas}

Pengujian ada tidaknya gejala multikolinieritas dilakukan dengan memperhatikan nilai matriks korelasi yang dihasilkan saat pengolahan data serta nilai VIF (Variance Inflation Factor) dan toleransinya. Jika nilai VIF berada dibawah 10 dan nilai toleransi mendekati 1, maka model regresi tersebut tidak terdapat multikolinieritas.

\section{TABEL VIII}

Uji Multikolineritas

\begin{tabular}{|c|c|c|c|}
\hline \multicolumn{4}{|c|}{ Coefficients $^{\mathrm{a}}$} \\
\hline \multirow{2}{*}{\multicolumn{2}{|c|}{ Model }} & \multicolumn{2}{|c|}{ Collinearity Statistics } \\
\hline & & Tolerance & VIF \\
\hline \multirow[t]{5}{*}{1} & (Constant) & & \\
\hline & $\mathrm{x} 1$ & .868 & 1.152 \\
\hline & $\mathrm{x} 2$ & .847 & 1.180 \\
\hline & $\mathrm{x} 3$ & .934 & 1.071 \\
\hline & $\mathrm{x} 4$ & .914 & 1.094 \\
\hline \multicolumn{4}{|c|}{ a. Dependent Variable: $y$} \\
\hline
\end{tabular}
tolerance yaitu 0.868 dengan nilai VIF sebesar 1.152 . Variabel perceived ease of use (X2) nilai tolerance yaitu 0.847 dan nilai VIF sebesar 1.180. variabel attitude towards using technology (X3) nilai tolerance yaitu 0.934 dan nilai VIF sebesar 1.071 dan variabel behavioral technology use (X4) nilai tolerence yaitu 0.914 dengan nilai VIF sebesar 1.094 Apabila VIF < 10, maka untuk uji multikolinieritas tidak terdapat persoalan diantara variabel bebas.

4) Uji Heteroskedastisitas

Uji heteroskedastisitas dilakukan dengan melihat grafik scatter plot antar nilai prediksi variabel terikat (ZPRED) dan nilai residualnya (SRESID). Jika titiktitik membentuk pola tertentu yang teratur seperti gelombang besar melebar, kemudian menyempit maka terjadi heteroskedastisitas. Jika titik-titik menyebar diatas dan dibawah angka 0 pada sumbu Y tanpa membentuk pola tertentu, maka tidak terjadi heteroskedastisitas.

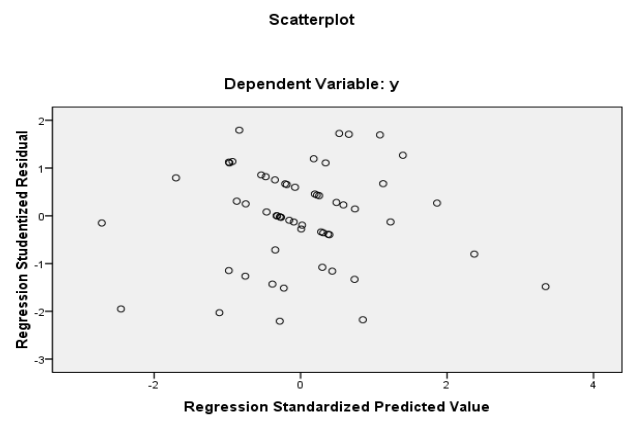

Gambar 6. Uji Heteroskedastisitas

Titik-titik pada grafik scatterplotdiatas, tidak mempunyai pola penyebaran yang jelas dan titik-titik menyebar di atas dan dibawah angka 0 pada sumbu Y. Hal ini menunjukkan bahwa tidak terdapat gangguan heteroskedastisitas pada model regresi.

4. Analisis Regresi Berganda

Analisis regresi berganda dilakukan untuk mencari manfaat antara konstruk usefulness (X1), konstruk ease of use (X2), konstruk attitude towards using 
Jurnal Ilmiah Rekayasa dan Manajemen Sistem Informasi, Vol. 5, No. 1, Februari 2019, Hal. 78-85

e-ISSN 2502-8995 p-ISSN 2460-8181

technology (X3) dan konstruk behavioral intention to use (X4) terhadap konstruk Actual technology use (Y).

TABEL IX

Analisis Regresi Berganda

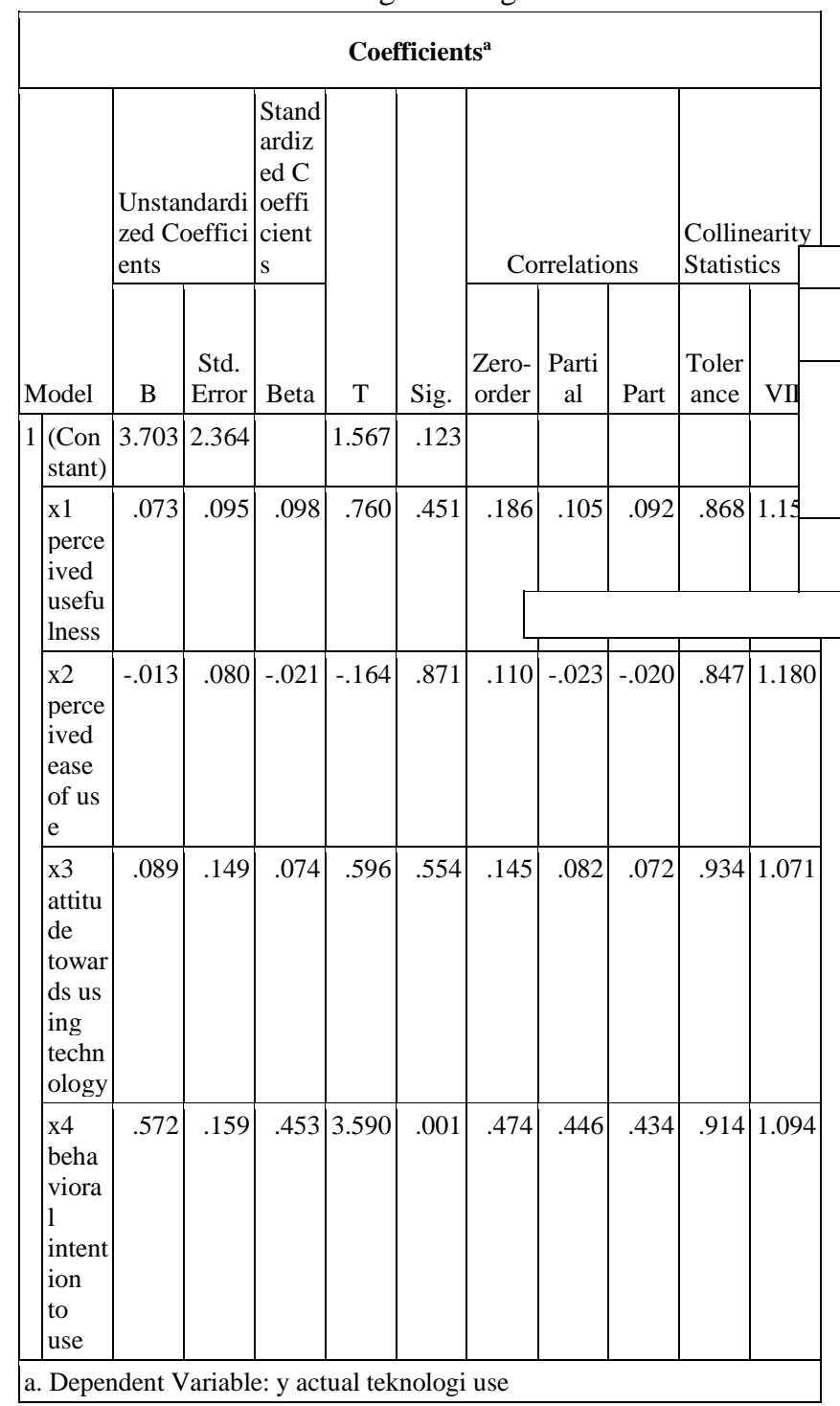

Berdasarkan tabel IX diatas, maka diperoleh persamaan regresi yang dihasilkan adalah:

\section{$\mathrm{Y}=3.703+0.073 \mathrm{X} 1+(-0.013) \mathrm{X} 2+0.089 \mathrm{X} 3+0.572 X 4$}

Berdasarkan hasil penelitian yang dilakukan dapat diketahui bahwa variabel usefulness, ease of use, attitude towards using technology, behavioral intention dan actual technology dan manfaat Sistem KS berpengaruh positif dan signifikan terhadap manfaat KS karyawan PT. PLN. Sektor Pembangkitan Pekanbaru dengan taraf signifikan terendah yaitu ease of use sistem KS (-013), dan taraf signifikan tertinggi yaitu variabel behavioral intention to use penggunaan Sistem KS (0.572).

\section{Hipotesis}

Untuk menentukan pengujian hipotesis maka dilakukan uji koefesien regresi secara simultan (uji f)

TABEL $X$

Uji Koefisien Regresi secara Simultan (Uji F)

\begin{tabular}{|l|l|l|l|l|l|}
\hline \multicolumn{7}{|c|}{ ANOVA $^{\text {b }}$} \\
Model & $\begin{array}{l}\text { Sum } \\
\text { Squares }\end{array}$ & df & Mean Square & F & Sig. \\
\hline $\begin{array}{l}\text { Regressio } \\
\text { Residual }\end{array}$ & 32.052 & 5 & 8.013 & 4.146 & $.005^{\text {a }}$ \\
\hline Total & 100.509 & 52 & 1.933 & & \\
\hline \\
a. Predictors: (Constant), x4behavioralintentiontouse, \\
b. Dependent Variable: yactualteknologiuse \\
\hline
\end{tabular}

\section{KESIMPULAN}

Kesimpulan yang didapat setelah penelitian ini diselesaikan adalah :

1. Tingkat manfaat knowledge sharing termasuk dalam kategori setuju dengan nilai tertinggi terdapat pada konstruk perceived ease of use sebesar 24,22\%, ini mengindikasikan bahwa karyawan telah merasakan kemudahan dalam menggunakan sistem knowledge management PLN pada knowledge sharing. Sedangkan nilai terendah terdapat pada konstruk perceived usefulness sebesar 15,96\%, menunjukkan bahwa karyawan belum banyak merasakan akan manfaat sistem knowledge management PLN pada Knowledge Sharing.

2. Karyawan telah merasakan manfaat knowledge sharing sehingga karyawan lebih banyak memilih kategori setuju dam yang sering menggunakan sistem knowledge management PLN pada knowledge sharing adalah bagian sumber daya manusia, sedangkan yang paling 
banyak merasakan manfaat knowledge

sharing adalah bagian operasi dan pemeliharaan

\section{REFERENSI}

[1] Sintaasih, Desak Ketut, "Knowledge Management Dan Peran Strategic Partner SDM: Pengaruhnya Terhadap Perencanaan Strategik Dan Kinerja Organisasi (Studi Pada Rumah Sakit Di Bali)." Jurnal Manajemen Dan Kewirausahaan, Vol. 13 No.1, Maret 2011.

[2] Putri, Amalia Hastyanti "Evaluasi Implementasi Knowledge Management System PT. Telekomunika si Indonesia" Jurnal Universitas Airlangga, Vol 2 No. 2, Hal 2-5, 2013.

[3] Mathar, Fadhilah. "Performasi Transfer Pengetahuan di Sektor Publik" Semantik, 2011.

[4] Setiarso, Bambang. 2005. “Knowledge Management Dan Penciptaan Pengetahuan”. Desember 2005, LIPI, Jakarta.

[5] Putra, Ondra Eka "Analisa Dan Implamentasi Knowledge Management System” Padang. 2013.

[6] Fatmasari, Ariandi Muhammad "Prediksi Tingkat Keyakinan Mahasiswa Akan Manfaat Fasilitas KRS Online Dengan Menggunakan Metode Technology Acceptance Model (TAM) ’ Palembang, 2014

[7] Novita, Dien., Dan Oktaviany, Della "Analisis Penerimaan Layanan Web Tracking Dengan Penerapan Technology Acceptance Model (TAM)" Vol. 3 No. 1 September 2016.

[8] Davis F. D. "Perceived Usefulness, Perceive Ease Of Use, And User Acceptance Of IT" Vol. 13. No.3 September, 1989.

[9] Paramida, Aldioctavia Vicka, Mudjahidin “Analisis Kemanfaatan Dan Kemudahan Penggunaan Aplikasi Manajemen Surat Dengan Pendekatan Technology Acceptance Model Pada PT. XYZ Surabaya” Vol. 3, No. 2, 2014. 